\title{
THE DISTRIBUTION OF TRANSFERRIN, GROUP-SPECIFIC COMPONENT AND PHOSPHOGLUCOMUTASE-1 SUBTYPES AMONG THE LEPCHAS OF DARJEELING, EASTERN INDIA
}

\author{
N. SAHa, ${ }^{1}$ B. MuKhopadhyay, ${ }^{2}$ S.K. BhatTaCharyya, ${ }^{3}$ \\ R. GuPta, ${ }^{2}$ and A. BASU ${ }^{2}$ \\ ${ }^{1}$ Department of Biochemistry, Faculty of Medicine, National University \\ of Singapore, Kent Ridge, Singapore 0511 \\ ${ }^{2}$ Anthropometry and Human Genetics Unit, and ${ }^{3}$ Biochemistry Unit, \\ India Statistical Institute, Calcutta, The Republic of India
}

\begin{abstract}
Summary The distribution of serum transferrin (Tf), group-specific component (Gc), and red cell phosphoglucomutase-1 (PGM1) subtypes has been studied by polyacrylamide gel and starch-gel electrophoresis followed by isoelectric focusing in a group of 213 Lepchas in the Darjeeling district, West Bengal, India. The frequencies of $T f^{\mathrm{Cl}}, T f^{\mathrm{C} 2}, T f^{\mathrm{B}}$ and $T f^{\mathrm{DChi}}$ were found to be $0.804,0.182,0.014$ and 0.00 , respectively, among the Buddhists and $0.741,0.244,0.007$ and 0.007 , respectively, in the Christian Lepchas. The frequencies of $\mathrm{Gc}$ alleles were as follows: $G c^{1 \mathrm{~F}} 0.587$ and $0.539 ; G c^{1 \mathrm{~S}}$ 0.203 and $0.242 ; G c^{2} 0.210$ and 0.215 in these two groups, respectively. The allelic frequencies of PGM1 were found to be 0.706 and 0.714 for $P G M^{1+} ; 0.164$ and 0.086 for $P G M^{1-} ; 0.116$ and 0.175 for $P G M^{2-}$ in Buddhists and Christians, respectively. No rare allele of Tf and PGM1 had been detected but one example of a variant from of $G c^{2}$ allele has been observed among the Christians.
\end{abstract}

\section{INTRODUCTION}

The introduction of isoelectric focusing (IEF) in the study of blood genetic markers enables a more refined and detailed investigation of the polymorphic system to be carried out than earlier studies by either starch-gel or polyacrylamide-gel electrophoresis. The most-studied blood genetic markers by IEF are serum transferrin (Tf), group-specific component (Gc) and red cell phosphoglucomutase-locus 1 (PGM1) (Kühnl and Spielman, 1978, 1979; Cleve et al., 1978; Constans and Viau, 1977; Constans and Cleve, 1979; Constans et al., 1979; Bark et al., 1976). Very limited data

Received May 23, 1986; revised version received September 23, 1987; Accepted October 6, 1987 
are available on these three polymorphisms in the populations of Asia, especially in the Indian regions. Earlier, we had reported results of limited studies on Tf and PGM polymorphisms (IEF) in several population groups of the Indian subcontinent (Saha and Tan, 1983; Saha, 1983, 1985). We present here the results of a study on the distribution of Tf, Gc, and PGM1 subtypes among a group of Lepchas in the Darjeeling district of West Bengal, Eastern India. The Lepchas are the original inhabitants of the Sikkim State at the foothills of the Himalayas and are quite distinct from the Nepalese, Bhutanese or Tibetans. They are inhabitants of high altitude. A detailed genetic study of the Lepchas with a description of their ethnological background has been presented elsewhere (Saha et al., 1987).

There have been very limited studies on the distribution of blood groups amongst the Lepchas in the past (Bhattacharjee, 1968; Miki et al., 1960a-c). No study had been carried out in this population on serum protein and red cell enzyme polymorphisms excepting our recent study on the Lepchas (Saha et al., 1987). In this paper we report on the distribution of serum Tf, Gc and red cell PGM1 subtypes in a group of Lepchas practising Buddhism or Christianity.

\section{MATERIALS AND METHODS}

The material of study comprised 213 Lepchas ( 73 Buddhists and 140 Christians of both sexes) living in the district of Darjeeling, West Bengal, India at the foothills of the Himalayas (altitude, 4,000 ft). Blood samples were collected by the fingerprick method described earlier (Saha and Kirk, 1973) into heparinized capillary tubes and onto Whatman $3 \mathrm{MM}$ filter paper strips. The capillary tubes and dried filter paper strips were placed in insulated containers in wet ice and brought to the Indian Statistical Institute, Calcutta. The plasma was separated by centrifuging the capillary tubes at low speed. Both the capillary tubes and filter paper strips were transported to our laboratory in Singapore, at wet-ice temperature.

Transferrin subtypes were determined by isoelectric focusing (IEF) using thin layer polyacrylamide gels (PAG) with LKB Ampholine of $\mathrm{pH} 3.5$ to 10 according to the method of Kühnl and Speilman, $(1978,1979)$. The serum samples were treated with neuraminidase before isoelectric focusing (Beckman et al., 1980). All the samples with rare variants like $\operatorname{Tf}^{B}$ and $T^{D}$ were re-run on thin layer PAG of pH 5-7 (LKB) for further clarification. The gels were stained with Coomassie Blue. The Gc subtypes were studied by PAG and IEF. The gels contained 2 per cent Pharmalyte of $\mathrm{pH} 4.0$ to 6.5 (Pharmacia). The isoelectric focusing was carried out after pre-run. Filter papers soaked with undiluted serum samples were used. After focusing the gels were fixed in 3 per cent sulfosalicylic acid solution in an ethanol-water mixture $(1: 2)$. After a few minutes the Gc phenotypes were read against a black background illuminated with fluorescent lamps from the side. After the reading the gels were stained with Coomassie Blue for record. Some of the samples were confirmed by immunofixation with antihuman Gc (Dako). In no case was the result different from that by the sulfosalicylic acid precipitation method. 
The red cell PGMI types were determined by starch-gel electrophoresis (Spencer et al., 1964) and isoelectric focusing on thin layer PAG-Ampholine gels of pH 5-7 (LKB) (Bark et al., 1976; Kühnl et al., 1977). Inserts were cut in size of $1 \mathrm{~cm} \times 5$ $\mathrm{mm}$ from blood-soaked dried filter paper ( $3 \mathrm{MM})$, soaked briefly in distilled water and applied directly on starch-gel and IEF gel, respectively, for electrophoresis and isoelectric focusing. After the run, the gels were stained by substrate mixture described by Spencer et al. (1964).

\section{RESULTS AND DISCUSSION}

Table 1 shows the observed and expected frequencies of different phenotypes and genes of the transferrin alleles among the Lepchas according to their religion. The phenotypic distribution was at equilibrium in both the groups of Lepchas. The frequencies of $T f^{\mathrm{C} 1}, T f^{\mathrm{C} 2}$ and $T f^{\mathrm{B}}$ amongst the Buddhists were $0.804,0.182$ and 0.013 , while the Christians had slightly different frequencies of these alleles $(0.741$, 0.244 and 0.007$)$ in addition to $T f^{\text {DChi }}(0.007)$. A similar frequency of $T f^{\mathrm{C} 2}$ has been reported in other Mongoloid populations like Japanese (Beckman et al., 1980; Kamboh and Kirk, 1983b) and Chinese (Tan et al., 1982; Kamboh and Kirk, 1983b; Saha, 1985, 1987). The frequencies of $T f^{\mathrm{B}}$ and $T f^{\mathrm{DChi}}$ in the present Lepcha population are also similar to those in the Chinese, Japanese, Nepalese and Bhutanese (Beckman et al., 1980; Kamboh and Kirk, 1983b; Tan et al., 1982; Sunderland et al., 1979; Mourant et al., 1968; Glassgow et al., 1968). The frequencies of Tf alleles in the present Lepcha population is not very different from those reported in diverse groups of Indian populations (Saha, 1987; Saha and Tan, 1983; Kamboh and Kirk, 1983b; Reddy et al., 1984; Walter et al., 1981, 1983).

Table 1. Distribution of transferrin subtypes among the Lepcha.

\begin{tabular}{|c|c|c|c|c|c|c|}
\hline \multirow{2}{*}{ Phenotypes } & \multicolumn{2}{|c|}{ Buddhists } & \multicolumn{2}{|c|}{ Christians } & \multicolumn{2}{|c|}{ All } \\
\hline & No. obs. & No. exp. & No. obs. & No. exp. & No. obs. & No. exp. \\
\hline $\mathrm{C} 1-1$ & 49 & 47.8 & 75 & 74.1 & 124 & 121.7 \\
\hline $\mathrm{C} 2-1$ & 19 & 21.7 & 46 & 48.8 & 65 & 70.8 \\
\hline $\mathrm{C} 2-2$ & 4 & 2.5 & 10 & 8.0 & 14 & 10.3 \\
\hline C1-B & 2 & 1.7 & 2 & 1.4 & 4 & 3.2 \\
\hline Cl-D & 0 & 0.0 & 2 & 1.4 & 2 & 1.6 \\
\hline Total & 74 & 73.7 & 135 & 133.7 & 209 & 207.6 \\
\hline \multicolumn{7}{|c|}{ Gene frequencies } \\
\hline$T f \mathrm{Cl}$ & \multicolumn{2}{|c|}{0.804} & \multicolumn{2}{|c|}{0.741} & \multicolumn{2}{|c|}{0.763} \\
\hline$T f \mathrm{C} 2$ & \multicolumn{2}{|c|}{0.182} & \multicolumn{2}{|c|}{0.244} & \multicolumn{2}{|c|}{0.222} \\
\hline$T f^{\prime} \mathrm{B}$ & \multicolumn{2}{|c|}{0.014} & \multicolumn{2}{|c|}{0.007} & \multicolumn{2}{|c|}{0.010} \\
\hline$T f \mathrm{DChi}$ & \multicolumn{2}{|c|}{0.0} & \multicolumn{2}{|c|}{0.007} & \multicolumn{2}{|c|}{0.005} \\
\hline
\end{tabular}


Table 2 shows the distribution of observed and expected frequencies of different phenotypes and genes of the Gc alleles in the Lepchas according to their religion. The phenotypic distribution was at equilibrium in both the groups of Lepchas. The frequencies of $G c^{\mathrm{IF}}, G c^{1 \mathrm{~S}}$ and $G c^{2}$ have been found to be $0.587,0.203$ and 0.210 among the Buddhists, while those in Christians were $0.539,0.242$ and 0.215 . A solitary example of a rare phenotype designated $2^{\prime}-1 \mathrm{~F}$ has been encountered in the latter group. It was not possible to identify this new allele due to lack of reference sample. The Japanese and Chinese had a lower frequency of $G c^{1 \mathrm{~F}}$ and a higher frequency of $G c^{2}$ (Ishimoto et al., 1979; Matsumoto et al., 1980; Kim and Lewis, 1981; Saha, 1985). However, the Indian population groups have a very low frequency of $G c^{1 \mathrm{~F}}$ in contrast to the Mongoloid populations (Papiha et al., 1981, 1982; Karlsson et al., 1983; Walter et al., 1984). The Tibetans have been reported to have a lower frequency of $G c^{1 \mathrm{~F}}(0.364)$ and higher frequencies of $G c^{1 \mathrm{~S}}$ and $G c^{2}$ than either Indian populations or other Mongoloid populations (Omoto and Miyake, 1978; Constans et al., 1979; Matsumoto et al., 1980; Kim and Lewis, 1981; Kamboh et al., 1984b; Saha, 1985). The frequency of $G c_{1}{ }^{F}$ in the present Lepcha populations is intermediate between the Mongoloid populations (Chinese and Japanese) and Indians. From the above it appears that the subtyping of $\mathrm{Gc}$ alleles might prove to be a better discriminatory marker in the study of the ethnogenetics rather than Gc typing by PAG and starch-gel electrophoresis.

Table 2. Distribution of group-specific component subtypes among the Lepcha.

\begin{tabular}{|c|c|c|c|c|c|c|}
\hline \multirow{2}{*}{ Phenotypes } & \multicolumn{2}{|c|}{ Buddhists } & \multicolumn{2}{|c|}{ Christians } & \multicolumn{2}{|c|}{ All } \\
\hline & No. obs. & No. exp. & No. obs. & No. exp. & No. obs. & No. exp. \\
\hline $1 \mathrm{~F}$ & 24 & 23.8 & 40 & 37.6 & 64 & 61.3 \\
\hline $1 \mathrm{~F}-1 \mathrm{~S}$ & 13 & 16.4 & 36 & 33.9 & 49 & 50.6 \\
\hline 1S & 6 & $2.8^{\mathrm{a}}$ & 6 & 7.6 & 12 & 10.4 \\
\hline $2-1 \mathrm{~F}$ & 20 & 17.0 & 23 & 30.1 & 43 & 47.3 \\
\hline $2-1 S$ & 3 & 5.9 & 15 & 13.5 & 18 & 19.5 \\
\hline 2 & 3 & 3.1 & 9 & 6.0 & 12 & 9.1 \\
\hline $2^{\prime}-1 F^{b}$ & 0 & 0.0 & 1 & 0.6 & 1 & 0.7 \\
\hline Total & 69 & 69.0 & 130 & 129.3 & 199 & 198.8 \\
\hline \multicolumn{7}{|c|}{ Gene frequencies } \\
\hline$G c^{1 F}$ & \multicolumn{2}{|c|}{0.587} & \multicolumn{2}{|c|}{0.538} & \multicolumn{2}{|c|}{0.555} \\
\hline$G c 1 \mathrm{~S}$ & \multicolumn{2}{|c|}{0.203} & \multicolumn{2}{|c|}{0.242} & \multicolumn{2}{|c|}{0.229} \\
\hline$G c^{2}$ & \multicolumn{2}{|c|}{0.210} & \multicolumn{2}{|c|}{0.215} & \multicolumn{2}{|c|}{0.214} \\
\hline$G c^{2^{\prime}}$ & \multicolumn{2}{|c|}{0.0} & \multicolumn{2}{|c|}{0.004} & \multicolumn{2}{|c|}{0.003} \\
\hline
\end{tabular}

${ }^{\mathrm{a}} \chi_{1}{ }^{2}=3.52$. b See text. 
Table 3 shows the phenotypic and genotypic distribution of the red cell phosphoglucomutase (locus 1) in the Lepchas according to their religion. The phenotypic distribution was at equilibrium in both the groups of Lepchas. The frequencies of $P G M^{1+}, P G M^{1-}, P G M^{2+}$, and $P G M^{2-}$ were found to be $0.706,0.164,0.116$, and 0.014 , respectively, in the Buddhists and $0.714,0.086,0.175$, and 0.025 , respectively, in the Christian group. No other rare allele at the PGM1 locus was detected among the Lepchas. Similar frequencies of PGM1 alleles have been reported in the Japanese (Maneyama et al., 1978; Nishigaki et al., 1982; Kamboh and Kirk, 1983a, 1984a). However, the Thais and Chinese have been reported to have lower frequencies of $P G M^{1+}$ and higher frequencies of $P G M^{2-}$ (Kamboh and Kirk, 1984a; Saha, 1983, 1985). One example of PGM 6-1 has been detected in the Lepchas by starch-gel electrophoresis (Saha et al., 1987). This sample could not be tested by IEF as the sample had been exhausted. Indians in general have been reported to have slightly lower frequency of $P G M^{1+}$ (Papiha et al., 1981, 1982; Saha, 1983; Kamboh and Kirk, 1984a).

Minor differences in the frequencies of some alleles at the $\mathrm{Tf}, \mathrm{Gc}$ and PGM1 loci have been observed between these two groups. The Buddhists had a higher

Table 3. Distribution of phosphoglucomutase (locus 1) subtypes among the Lepcha.

\begin{tabular}{|c|c|c|c|c|c|c|}
\hline \multirow{2}{*}{ Phenotypes } & \multicolumn{2}{|c|}{ Buddhists } & \multicolumn{2}{|c|}{ Christians } & \multicolumn{2}{|c|}{ All } \\
\hline & No. obs. & No. exp. & No. obs. & No. exp. & No. obs. & No. exp. \\
\hline $1^{+}$ & 35 & 36.3 & 73 & 71.4 & 108 & 107.7 \\
\hline $1^{+} 1^{-}$ & 17 & 16.9 & 19 & 17.2 & 36 & 34.2 \\
\hline $1^{-}$ & 2 & 2.0 & 1 & 1.0 & 3 & 2.7 \\
\hline $1^{+} 2^{+}$ & 14 & 12.0 & 33 & 35.0 & 47 & 46.9 \\
\hline $1^{-2} 2^{+}$ & 3 & 2.8 & 3 & 4.2 & 6 & 7.5 \\
\hline $1^{+} 2^{-}$ & 2 & 1.4 & 2 & 5.0 & 4 & 6.4 \\
\hline $1^{-2-}$ & 0 & 0.3 & 0 & 0.6 & 0 & 1.0 \\
\hline $2^{+}$ & 0 & 1.0 & 6 & 4.3 & 6 & 5.1 \\
\hline $2^{+} 2^{-}$ & 0 & 0.2 & 1 & 1.2 & 1 & 1.4 \\
\hline $2^{-}$ & 0 & 0.0 & 2 & $0.1^{\mathrm{a}}$ & 2 & 0.1 \\
\hline Total & 73 & 72.9 & 140 & 140.0 & 213 & 213.0 \\
\hline
\end{tabular}

Gene frequencies

$\begin{array}{llll}P G M^{1+} & 0.705 & 0.714 & 0.711 \\ P G M^{1-} & 0.164 & 0.086 & 0.113 \\ P G M^{2+} & 0.116 & 0.175 & 0.155 \\ P G M^{2-} & 0.014 & 0.025 & 0.021\end{array}$

${ }^{a} \chi_{1}{ }^{2}=40.53$ (due to small expected number). 
frequency of $T f^{\mathrm{Cl}}(0.804), T f^{\mathrm{B}}(0.01), G c^{1 \mathrm{~F}}(0.587), P G M^{1-}(0.164)$ and lower frequency of $P G M^{2+}$ compared to those in the Christian Lepchas. $T f^{D C h i}$ was present among the Christians $(0.01)$ but not in the Buddhists. There appear to be more foreign gene pools among the Christians which is also supported by earlier observation of increased heterozygosity in the same group (Saha et al., 1987).

Acknowledgments The authors are grateful to Mdm C.H. Ho and Miss Jumiah bte Basir for excellent technical assistance and Miss Fannie Chan for secretarial assistance. The study was generously supported by grants from the Shaw Foundation and Singapore Turf Club.

\section{REFERENCES}

Bark, J.E., Harris, M.J., and Firth, M. 1976. Typing of the common phosphoglucomutase variants, using isoelectric focusing-a new interpretation of the phosphoglucomutase systems. J. Forens. Sci. Soc. 16: 115-120.

Beckman, G., Beckman, L., and Sikström, C. 1980. Transferrin C subtypes in different ethnic groups. Hereditas 92: 189-192.

Bhattacharjee, P.N. 1968. Serogenetic variations in the Lepchas of Darjeeling district with special reference to the Indian Mongoloid. Bull. Anthropol. Surv. India 17: 383-392.

Cleve, H., Patutschnick, W., Nevo, S., and Wendt, G.G. 1978. Genetic studies of the Ge subtypes. Hum. Genet. 44: 117-122.

Constans, J. and Cleve, H. 1979. Group-specific component. Report of the Frist International Workshop. Hum. Genet. 48: 143-148.

Constans, J. and Viau, M. 1977. Group-specific component: evidence for two subtypes of the $\mathrm{Gc}^{1}$ gene. Science 198: 1070-1071.

Constans, J., Viau, M., Moatti, J.P,, and Clavere, J.L. 1979. Serum vitamin D binding protein and Ge polymorphisms. In Vitamin D, Basic Research with Clinical Application, Walter de Gruyler, Berlin/N.Y. pp. 153-156.

Glassgow, B.G., Goodwin, M.J., Jackson, F., Kopèc, A.C., Lehman, H., Mourant, A.E., Tills, D., Turner, R.W.D., and Ward, M.P. 1968. The blood groups, serum groups and haemoglobin of the inhabitants of Luana and Timbu, Bhutan. Vox. Sang. 14: 31-42.

Ishimoto, G., Kwata, M., and Nakajima, H. 1979. Group-specific component (Gc) polymorphism in Japanese: an isoelectric focusing on polyacrylamide gels. Hum. Genet. 24: 75-83.

Kamboh, M.I. and Kirk, R.L. 1983a. Investigation of $\mathrm{PGM}_{1} 3$, $\mathrm{PGM}_{1} 6$ and $\mathrm{PGM}_{1} 7$ variants by isoelectric focussing. Evidence for new subtypes of the $\mathrm{PGM}_{1}{ }^{3}$ and $\mathrm{PGM}_{1}{ }^{7}$ alleles. Hum. Genet. 64: 58-60.

Kamboh, M.I. and Kirk, R.L. 1983b. Distribution of transferrin (Tf) subtypes in Asian, Pacific and Australian aboriginal populations: evidence for the existence of a new subtype TfC6. Hum. Hered. 33: 237-243.

Kamboh, M.I. and Kirk, R.L. 1984a. Genetic studies of PGM1 subtypes: population data from Asian-Pacific area. Ann. Hum. Biol. 11: 211-219.

Kamboh, M.I., Ranford, P.R., and Kirk, R.L. 1984b. Population genetics of the vitamin D binding protein $(\mathrm{Gc})$ subtypes in the Asian Pacific area: description of new alleles at the Gc locus. Hum. Genet. 67 : 378-384.

Karlsson, S., Skaftadottir, 1., Arnason, A., Mackintosh, P., and Jensson, O. 1983. Ge subtypes in Northern Indians. Hum. Hered. 33: 199-200.

Kim, Y.Y.K. and Lewis, W.H.P. 1981. Group-specific (Gc) subtypes in the Chinese population of Hong Kong. Hum. Genet. 59: 72-74. 
Kühnl, P., Schmidtmann, U., and Spielmann, W. 1977. Evidence of two additional common alleles at the PGM1 locus [phosphoglucomutase, EC 2.7.5.1]. A comparison by three different techniques. Hum. Genet. 35: 219-223.

Kühnl, P. and Spielmann, W. 1978. Transferrin: evidence for two common subtypes of the TfC alleles. Hum. Genet. 43: 91-95.

Kühnl, P. and Spielmann, W. 1979. A third common allele in the transferrin system, TfC3, detected by isoelectric focusing. Hum. Genet. 50: 193-198.

Maneyama, Y., Horai, S., and Omoto, K. 1978. The distribution of the phosphoglucomutase-1 $\left(\mathrm{PGM}_{1}\right)$ subtypes in Japanese. Jpn. J. Human Genet. 23: 383-387.

Matsumoto, H., Matsui, K., Ishida, N., Ohkura, K., and Teng, Y.S. 1980. The distribution of Gc subtypes among the Mongoloid populations. Am. J. Phys. Anthropol. 53: 505-508.

Miki, T., Tanaka, T., and Furuhata, T. 1960a. On the distribution of ABO blood groups and the taste ability for phenyl-thiocarbamide (P.T.C.) of the Lepchas and the Khasis. Proc. Jpn. Acad. 36: 78-80.

Miki, T., Tanaka, T., and Furuhata, T. 1960b. On the distribution of MN, P, and Rh blood types of the Lepchas and the Khasis. Proc. Jpn. Acad. 36: 168-171.

Miki, T., Tanaka, T., Hayashida, Y., and Furuhata, T, 1960c. On the distribution of secretor character of the Lepchas and the Khasis. Proc. Jpn. Acad. 36: 229-233.

Mourant, A.E., Godber, M.J., Kopèc, A.C., Lehmann, H., Steele, P.R., and Tills, D. 1968. The hereditary blood factors of some populations in Bhutan. Anthropologist, special volume, pp. 29-43.

Nishigaki, I., Benkman, H.-G., and Goedde, H.W. 1982. Isoelectric focusing studies of human red cell PGM1 in Japanese, with special reference to the characterization of $\mathrm{PGM}_{1} 7$. Hum. Hered. 32: 301-207.

Omoto, K. and Miyake, K. 1978. The distribution of the group-specific component (Gc) subtypes in Japanese. Jpn. J. Human Genet. 23: 119-125.

Papiha, S.S., Roberts, D.F., White, I., Chahal, S.M.S., and Asefi, J.A. 1982. Population genetics of the group-specific component (Gc) and phosphoglucomutase (PGM1) studied by isoelectric fosucing. Am. J. Phys. Anthropol. 59: 1-7.

Papiha, S.S., White, I., and Chahal, S.M.S., 1981. Study of phosphoglucomutase polymorphism by isoelectric focusing: gene frequencies in the Gaddi tribe of Himachal Pradesh, India. Ann. Hum. Biol. 8: 379-382.

Reddy, A.P., Mukherjee, B.N., Malhotra, K.C., Walter, H., and Sauber, P. 1984. Transferrin subtyping by isoelectro focusing in three West Bengal populations. Z. Morph. Anthropol. 74: 345-349.

Saha, N. 1983. Red cell phosphoglucomutase $1\left(\mathrm{PGM}_{1}\right)$ subtypes in three ethnic groups of Singapore. Proceedings of the XVth International Congress of Geneiics, New Delhi, abstract p. 776.

Saha, N, 1985. Transferrin, group-specific component and phosphoglucomutase subtypes in some populations of the South East Asian region. Proc. Int. Meeting of the Genetic Diversity and its Maintenance in Tropical Population. Rome, 1st-4th April.

Saha, N. 1987. Distribution of transferrin (Tf) subtypes in several Mongoloid populations of East Asia. Ann. Hum. Biol. in press.

Saha, N., Bhattacharyya, S.P., Mukhopadhaya, B., Bhattacharyya, S.K., Gupta, R., and Basu, A. 1987. A genetic study among the Lepchas of the Darjeeling area of Eastern India. Hum. Hered. 37 : 113-121.

Saha, N. and Kirk, R.L. 1973. A simple technique for collecting blood for population studies of enzyme polymorphisms and haemoglobins. Hum. Hered. 23: 182-187.

Saha, N. and Tan, P.Y. 1983. Transferrin C subtypes among some populations of the Indian subcontinent. Ann. Hum. Biol. 10:84-85.

Spencer, N., Hopkinson, D.A., and Harris, H. 1964. Phosphoglucomutase polymorphism in man. Nature 204: $742-745$. 
Sunderland, E., Sawhney, K.S., and Bethell, I.L. 1979. Plasma protein and red cell enzyme groups among the Nepalese. Hum. Hered. 29: 14-26.

Tan, S.G., Gan, Y.Y., and Asuan, K. 1982. Transferrin C subtyping in Malaysians and in Indonesians from North Sumatra. Hum. Genet, 60: 369-370.

Walter, H., Dannewitz, A., Veerraju, P., and Goud, J.D. 1984. Gc subtyping in South Indian tribal and caste populations. Hum. Hered. 34: 250-254.

Walter, H., Stach, M., Singh, I.P., and Bhasin, M.M. 1983. Transferrin subtypes in four Northwest Indian tribal populations and some remarks on the anthropological value of this new polymorphism. Am. J. Phys. Anthropol. 61, 423-428.

Walter, H., Strödtmann, H., Hilling, M., Singh, I.P., Bhasin, M.K., and Veerraju, P. 1981. Transferrin subtypes in six Indian population samples. Hum. Hered. 31: 152-155. 